\title{
HAEMATOLOGICAL CHANGES AND THEIR CORRELATION WITH THE DEGREE OF RENAL INSUFFICIENCY IN NEWLY DETECTED TYPE 2 DIABETES PATIENTS ATTENDING JNIMS OPD
}

\author{
Kh. Rochitra Devi', Ksh. Achouba Singh'2, Y. Mohan Singh ${ }^{3}$
}

1 Postgraduate Student, Department of Pathology, Jawaharlal Nehru Institute of Medical Sciences (JNIMS), Imphal, Manipur, India. ${ }^{2}$ Associate Professor, Department of Endocrinology, Jawaharlal Nehru Institute of Medical Sciences (JNIMS), Imphal, Manipur, India. 3 Professor and HOD, Department of Pathology, Jawaharlal Nehru Institute of Medical Sciences (JNIMS), Imphal, Manipur, India.

\section{ABSTRACT}

\section{BACKGROUND}

There is an increasing number of patients with diabetes over the past decades, leading to higher incidence of chronic kidney disease in the affected group of patients. Haematological changes are well known clinical abnormality in patients with deteriorated renal function, which is emerging as a major health issue.

In this study, we analysed the correlation of haematological changes with the degree of renal insufficiency in type II diabetes patients.

\section{MATERIALS AND METHODS}

This descriptive study was carried out from September 2015 to September 2017 for a period of 25 months in the Department of Pathology, and Diabetes OPD, Jawaharlal Nehru Institute of Medical Sciences, Porompat, Imphal. A total of 250 (two hundred and fifty) newly diagnosed diabetes cases from both the sexes were included in the study, as per inclusion and exclusion criteria. Diagnosis of the Diabetes was considered by following the criteria laid down by the American Diabetes Association, the European Association for the Study of Diabetes, and the International Diabetes Federation. All tests were carried out under standard procedure.

\section{RESULTS}

A total of 250 patients were taken for study. Maximum number of patients (65.2\%) were found to be in the age group of 35-55 years. Majority of the patients $(n=161)$ in the study were in stage 1 CKD followed by stage $2(n=75)$ and stage $3 a(n=12)$ and one patient in each of stage $3 \mathrm{~b}$ and stage 4 CKD. Haemoglobin ranged from $6.9 \mathrm{gm} \%$ to $17.9 \mathrm{gm} \%$ with a mean haemoglobin of 13.28 gm\%. Anaemia was prevalent in $20 \%$ of the cases. Mean Haematocrit or Packed Cell Volume was found to be $40.92 \pm 6.168 \%$ and was statistically significant ( $p$ value $0.027<0.05$ ). Mean ESR was found to be $25.64 \pm 19.089 \mathrm{~mm} / 1$ st hour and $p$-value was statistically significant $(\mathrm{p}$ value $=0.011<0.05$ ). Mean Absolute Eosinophil Count was found to be statistically significant ( $\mathrm{p}$ value=0.035). Mean TLC, RDW, MCH, MCV, MCHC, Absolute Counts of Neutrophil, Lymphocyte and Monocyte were found to be not significant statistically.

\section{CONCLUSION}

Haematologic abnormalities are common in Diabetes, especially when associated with renal dysfunction. Anaemia is the most common haematologic abnormality observed. Normocytic normochromic anaemia and Microcytic hypochromic anaemia are the two types of anaemia observed. Maximum number of cases were in stage 1 of CKD with eGFR $>90 \mathrm{~mL} / \mathrm{min} / 1.73 \mathrm{~m}{ }^{2}$. This may be because, in this study there were only newly diagnosed type 2 diabetes mellitus cases. ESR was higher with a mean value of $25.64 \pm 19.089 \mathrm{~mm} / 1^{\text {st }}$ hour and shows positive correlation with stages of CKD. The haematocrit was found to be statistically significant upon correlation with stages of CKD.

\section{KEY WORDS}

Diabetes Mellitus, Renal Insufficiency, Anaemia, Erythrocyte Sedimentation Rate, Haematocrit.

HOW TO CITE THIS ARTICLE: Devi KR, Singh KA, Singh YM. Haematological changes and their correlation with the degree of renal insufficiency in newly detected type 2 diabetes patients attending JNIMS OPD. J. Evolution Med. Dent. Sci. 2018;7(31):3502-3508, DOI: $10.14260 /$ jemds/2018/788

\section{BACKGROUND}

Diabetes Mellitus (DM) refers to a group of common metabolic disorders that have the features of hyperglycaemia. Several types of DM are caused by a complex interaction of genetical factors and environmental factors.

'Financial or Other Competing Interest': None.

Submission 06-07-2018, Peer Review 20-07-2018,

Acceptance 23-07-2018, Published 30-07-2018.

Corresponding Author:

Dr. Ksh. Achouba Singh

Associate Professor,

Uripok Bachaspati Maning Leikai,

Imphal, Manipur, India.

E-mail: drachoubasingh@yahoo.com

DOI: $10.14260 /$ jemds $/ 2018 / 788$
The metabolic abnormality associated with DM causes secondary pathophysiologic changes in multiple organ systems. There are two broad categories of DM designated as type 1 and type 2 . The prevalence of type $2 \mathrm{DM}$ is rising much more rapidly because of increasing obesity, reduced activity levels of individuals, countries become more and more industrialised and the increasing section of aging of the population. The worldwide prevalence of DM has risen dramatically from an estimated 30 million cases in 1985 to 285 million in 2010. International Diabetes Federation projects that 438 million individuals will have diabetes by the year 2030.1 
Criteria for the Diagnosis of Diabetes Mellitus ${ }^{1}$

- Individuals having symptoms of diabetes plus random blood glucose level $\geq 11.1 \mathrm{mmol} / \mathrm{L}$ $(200 \mathrm{mg} / \mathrm{dL})$ or

- $\quad$ Fasting plasma glucose level $\geq 7.0 \mathrm{mmol} / \mathrm{L}$ $(126 \mathrm{mg} / \mathrm{dL})$ or

- $\quad$ HbA1C level $>6.5 \%$ or

- Two-hour plasma glucose level $\geq 11.1 \mathrm{mmol} / \mathrm{L} \mathrm{(200}$ $\mathrm{mg} / \mathrm{dL}$ ) during an oral glucose tolerance test

The countries with the greatest number of individuals with diabetes in 2013 are China with 98.4 million people, India with 65.1 million people, United States having 24.4 million diabetic individuals, Brazil with 11.9 million people and the Russian federation having 10.9 million people. 80\% of the individuals with diabetes live in low-income and medium-income countries. ${ }^{1}$

India comprises a largest hub of diabetics with 31.7 million cases of T2DM and a three-fold rise in disease prevalence in rural (2-6\%) and urban (5-15\%) areas. $^{2}$

Chronic Kidney Disease (CKD) and type 2 diabetes mellitus are increasing in populations and both are high-risk factors for the development of anaemia. ${ }^{3}$ Anaemia is an almost invariable manifestation of chronic renal failure, often contributing substantially to the morbidity of the condition. 4

The severity of anaemia bears a rough relationship to the degree of renal insufficiency. Anaemia is not routinely observed until the creatinine clearance falls to $<45$ $\mathrm{mL} /$ minute/1.73 $\mathrm{m}^{2}$ body surface area, which corresponds roughly to a serum creatinine of 2.0 to $2.5 \mathrm{mg} / \mathrm{mL}$ in an average-sized adult. ${ }^{5}$

In spite of the abundance of reports on the presence of anaemia in diabetic patients having renal insufficiency, there are limited studies on the prevalence of anaemia in newly diagnosed diabetics having renal insufficiency. Therefore, in order to increase the level of awareness and understanding of anaemia amongst diabetic patients, there is increasing need for more studies.

In the present study, therefore, we aimed at demonstrating the incidence of anaemia and renal insufficiency in newly detected type 2 diabetes mellitus.

\section{Aims and Objectives}

1. To study the haematological changes in newly detected/diagnosed Type 2 Diabetes.

2. To assess renal function in newly detected/diagnosed Type 2 Diabetes.

3. To find the correlation of haematological changes and renal insufficiency in newly detected Type 2 diabetes mellitus.

\section{MATERIALS AND METHODS}

This descriptive study 'Haematological changes and their correlation with degree of renal insufficiency in newly detected/diagnosed Type 2 Diabetes patients attending JNIMS OPD' was carried out from September 2015 to September 2017 for a period of 25 months in the Department of Pathology and Diabetes OPD, Jawaharlal Nehru Institute of Medical Sciences, Porompat, Imphal.

\section{Selection of Patients}

In the present study, patients were newly diagnosed with Type 2 diabetes mellitus attending the Diabetes OPD were included. Both male and female patients were included in the study. Diagnosis of the Diabetes were considered by following the criteria laid down by the American Diabetes Association, the European Association for the Study of Diabetes and the International Diabetes Federation-

1. A FPG level $\geq 7.0 \mathrm{mmol} / \mathrm{L}(126 \mathrm{mg} / \mathrm{dL})$, a glucose level $>11.1 \mathrm{mmol} / \mathrm{L}(200 \mathrm{mg} / \mathrm{dL})$ two hours after an oral glucose challenge or a $\mathrm{HbA1C}$ level $\geq 6.5 \%$.

2. A random plasma glucose level $\geq 11.1 \mathrm{mmol} / \mathrm{L}(200$ $\mathrm{mg} / \mathrm{dL}$ ) accompanied by the classic symptoms of DM (polyuria, polydipsia, weight loss) also is sufficient for the diagnosis of DM.

\section{Inclusion Criteria}

Newly diagnosed Type 2 diabetes (receiving oral hypoglycaemic drugs) attending Diabetes OPD in JNIMS.

\section{Exclusion Criteria}

1. Pregnancy associated diabetes.

2. Patients with any malignancy.

3. Patients having history of recent blood loss.

4. Patients with current or previous history of cytotoxic therapy.

5. Patients with current or previous erythropoietin therapy.

6. Patients with current or recent intravenous iron therapy.

7. Patients with recent history of blood transfusion.

8. Individuals on renal replacement therapy.

9. Patients having acute renal failure.

10. Hypertensive patients.

250 (Two hundred and fifty) newly diagnosed Diabetes cases from both the sexes were selected for the study. The proforma was developed to record information on demographics, co-morbidities, past history, history of presenting illness, physical findings and laboratory investigations. Their personal data and family history of diabetes mellitus and cardiovascular disease, duration and onset of diabetes as well as their drug history was obtained after taking proper consent. Body weight $(\mathrm{kg})$ in light clothes without shoes was measured.

After complete aseptic precautions, venous blood sample was drawn for laboratory evaluation of blood urea using Berthelot method, serum creatinine using Jaffe's method with colorimeter. Blood glucose (Fasting and Post-Prandial) level was determined.

Glycated haemoglobin was also determined. Complete haemogram was determined using the cell counter (Micros 60 Advia 60/ABC Vet). Peripheral blood smear was examination under the microscope. GFR (Glomerular Filtration Rate) were estimated using Cockcroft-Gault equation:

Estimated creatinine clearance

$(\mathrm{mL} / \mathrm{min})=(140-$ age $) \times$ body weight $(\mathrm{kg})$

$72 \times P_{C r}(\mathrm{mg} / \mathrm{dL})$

(Multiply by 0.85 for women)

Renal insufficiency was considered in patients having eGFR $<60 \mathrm{~mL} / \mathrm{min} / 1.73 \mathrm{~m}^{2}$. Urine samples were collected for routine urine examination and urine microalbumin determination. 
Microalbuminuria- Microalbuminuria tested using the test strips (Micral Test Strips).

The test strip is placed in the urine such that the fluid level is just between the 2 black bars making sure that it does not touch the sides of the test tube. After 5 seconds, test strip is withdrawn and placed across the top of urine vessel. After 1 minute, the colour is compared to the test pad given at the 'Micral' bottle. The screening result is positive when the reaction colour corresponds to $20 \mathrm{mg} / \mathrm{dL}$ or more.

\section{Statistical Analysis}

The results was subjected to statistical analysis using SPSS version 16.0. Descriptive statistics were mentioned as mean and standard deviation. Statistical analysis was done using One-Way ANOVA and independent sample ' $t$ ' test. Correlation of different components of DLC is done using Pearson correlation A probability level of $p<0.05$ was considered significant.

\section{Ethical Issues}

Informed written consent was taken from participating patients and the Ethical Committee approval was sought.

\section{RESULTS}

Two hundred and fifty (250) newly diagnosed diabetes cases were included in the study. There were 118 (47.2\%) males and 132 (52.8\%) females.

\begin{tabular}{|c|c|c|}
\hline & Frequency & Percent \\
\hline Female & 132 & 52.8 \\
\hline Male & 118 & 47.2 \\
\hline Total & $\mathbf{2 5 0}$ & $\mathbf{1 0 0 . 0}$ \\
\hline \multicolumn{3}{|c|}{ Table 1. Sex Distribution } \\
\hline
\end{tabular}

Table 1 shows the sex distribution of cases. It was observed that more number of patients were females $(n=132$, $52.8 \%)$ than males $(n=118,47.2 \%)$.

\begin{tabular}{|c|c|c|c|}
\hline \multicolumn{2}{|c|}{ Age (in Yrs.) } & Frequency & Percent \\
\hline \multirow{4}{*}{} & $15-35$ & 32 & 12.8 \\
\cline { 2 - 4 } & $35-55$ & 163 & 65.2 \\
\cline { 2 - 4 } & $55-75$ & 53 & 21.2 \\
\cline { 2 - 4 } & $>75$ & 2 & 0.8 \\
\cline { 2 - 4 } & Total & $\mathbf{2 5 0}$ & $\mathbf{1 0 0 . 0}$ \\
\hline \multicolumn{3}{|c|}{ Table 2 } \\
\hline
\end{tabular}

As evident in Table 2, the age range of the study population was from 16 to 80 years with mean age being 46.16 years. There were maximum number of patients in the age group 35-55 years of age (65.2\%) followed by $55-75$ years $(21.2 \%)$ and $15-35$ years $(12.8 \%)$, whereas minimum number of patients were above the age of 75 years $(0.8 \%)$.

\begin{tabular}{|c|c|c|c|c|c|c|}
\hline \multicolumn{7}{|c|}{ Stages of CKD with Age Cross Tabulation } \\
\hline & & \multicolumn{4}{|c|}{ Age (in Years) } & \multirow{2}{*}{ Total } \\
\hline & & 15-35 & $35-55$ & $55-75$ & $>75$ & \\
\hline \multirow{5}{*}{ Grades } & St1 & 30 & 113 & 18 & 0 & 161 \\
\hline & St 2 & 2 & 45 & 27 & 1 & 75 \\
\hline & St 3a & 0 & 4 & 8 & 0 & 12 \\
\hline & St 3b & 0 & 1 & 0 & 0 & 1 \\
\hline & St 4 & 0 & 0 & 0 & 1 & 1 \\
\hline \multicolumn{2}{|c|}{ Total } & 32 & 163 & 53 & 2 & 250 \\
\hline \multicolumn{7}{|c|}{ Table 3} \\
\hline
\end{tabular}

Table 3 shows the distribution of age at various stages of chronic kidney disease.

Maximum cases were of age group 35-55 years of age ( $n=163$ ), out of which 113 were in stage 1, 45 cases were in stage 2, 4 cases were in stage $3 \mathrm{a}$ and one case in stage $3 \mathrm{~b}$. Number of cases in younger age group (15-35 years) were 32 , out of which 30 cases were in stage 1 and 2 cases in stage 2 . Only 2 (two) cases were in older age group ( $>75$ years), of which one case was in stage 2 and another in stage 4 .

\begin{tabular}{|c|c|c|}
\hline Stage of CKD & No. of Patients & Percentage \\
\hline Stage 1 & 161 & $64.4 \%$ \\
\hline Stage 2 & 75 & $30 \%$ \\
\hline Stage 3a & 12 & $4.8 \%$ \\
\hline Stage 3b & 1 & $0.4 \%$ \\
\hline Stage 4 & 1 & $0.4 \%$ \\
\hline Stage 5 & 0 & $0 \%$ \\
\hline Total & $\mathbf{2 5 0}$ & $\mathbf{1 0 0} \%$ \\
\hline Table 4. Distribution in different stages of CKD \\
\hline
\end{tabular}

Table 4 shows the distribution of cases at different stages of Chronic Kidney Disease. Majority of cases were at stage 1 $(64.4 \%)$ with $30 \%$ cases at stage $2,4.8 \%$ cases at stage $3 a$ and $0.4 \%$ cases in each at stage $3 \mathrm{~b}$ and stage 4 . No cases were seen in stage 5 .

Haemoglobin ranged from $6.9 \mathrm{gm} \%$ to $17.9 \mathrm{gm} \%$ with a mean haemoglobin of $13.28 \mathrm{gm} \%$. The mean haemoglobin level in the different stages of CKD are given below.

\begin{tabular}{|c|c|c|c|}
\hline & Hb Mean \pm SD & F-value & P-value \\
\hline Stage $1(\mathrm{n}=161)$ & $13.79 \pm 1.949$ & 2.340 & 0.005 \\
\hline Stage $2(\mathrm{n}=75)$ & $13.16 \pm 1.855$ & \\
\cline { 1 - 3 } Stage 3a $(\mathrm{n}=12)$ & $12.82 \pm 1.309$ & \\
\cline { 1 - 3 } Stage 3b $(\mathrm{n}=1)$ & 11 & & \\
\cline { 1 - 3 } Stage 4 $(\mathrm{n}=1)$ & 13.5 & & \\
\cline { 1 - 3 } Table 5. Mean Haemoglobin distribution in various Stages \\
\hline
\end{tabular}

Haemoglobin level correlation with CKD was found to be highly significant ( $p$-value $<0.05$ ).

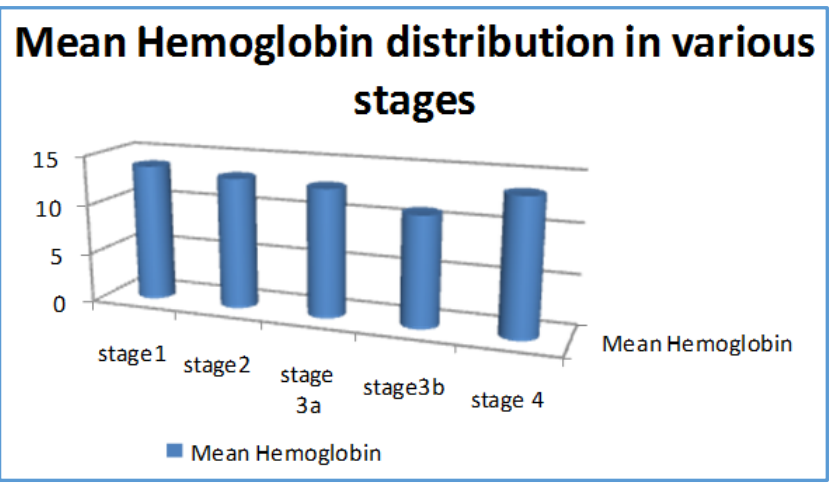

Figure 1. Shows the Mean distribution of Haemoglobin in various stages of Chronic Kidney Disease

\begin{tabular}{|c|c|c|}
\hline TLC/cmm & Frequency & Percent \\
\hline$<4000$ & 5 & 2.0 \\
\hline $4000-11000$ & 228 & 91.2 \\
\hline$>11000$ & 17 & 6.8 \\
\hline Total & $\mathbf{2 5 0}$ & $\mathbf{1 0 0 . 0}$ \\
\hline \multicolumn{2}{|c|}{ Table 6. Distribution of Total Leucocyte Count } \\
\hline
\end{tabular}


Table 6 illustrates maximum number of patients (91.2\%) have total leucocyte count within normal limit. Five $(2.0 \%)$ of the patients were found to have leucopenia. Seventeen patients $(6.8 \%)$ were found to have leucocytosis.

\begin{tabular}{|c|c|c|c|}
\hline & $\begin{array}{c}\text { TLC } \\
\text { Mean } \pm \text { SD }\end{array}$ & F -value & P-value \\
\hline Stage $1(\mathrm{n}=161)$ & $7921.02 \pm 2413.058$ & 0.335 & 0.850 \\
\hline Stage $2(\mathrm{n}=75)$ & $7929 \pm 2426.680$ & \\
\cline { 1 - 2 } Stage $3 \mathrm{a}(\mathrm{n}=12)$ & $7680.83 \pm 2235.346$ & \\
\cline { 1 - 2 } Stage $3 \mathrm{~b}(\mathrm{n}=1)$ & 5700.00 & \\
\cline { 1 - 2 } Stage $4(\mathrm{n}=1)$ & 9400.00 & \\
\cline { 1 - 2 } Table 7. Distribution of Mean Total Leucocyte Count at \\
different Stages \\
\hline
\end{tabular}

Table 7 shows mean distribution of Total Leucocyte Count at different stages/grades of chronic kidney disease. Mean TLC almost remain similar in stages 1, 2 and 3a, but there is sudden dip in the count in stage $3 \mathrm{~b}$. Stage 4 have a higher level than any other stages.

\begin{tabular}{|c|c|c|c|}
\hline \multicolumn{2}{|c|}{} & Frequency & Percent \\
\hline \multirow{4}{*}{} & High & 146 & 58.4 \\
\cline { 2 - 4 } & Normal & 104 & 41.6 \\
\cline { 2 - 4 } & Total & $\mathbf{2 5 0}$ & $\mathbf{1 0 0 . 0}$ \\
\hline \multicolumn{3}{|c|}{ Table 8. Distribution of ESR } \\
\hline
\end{tabular}

Table 8 shows frequency distribution of ESR. The Mean ESR (Erythrocyte Sedimentation Rate) values was found to be (25.54 \pm 19.089$) .58 .4 \%(n=146)$ of the patients were found to have higher ESR values than normal, while $41.6 \%(n=104)$ of the patients were found to have ESR values within normal limit. Majority of the patients have high ESR values (58.4\%), while $41.6 \%$ of the patients have ESR value within normal range.

\begin{tabular}{|c|c|c|c|}
\hline & $\begin{array}{c}\text { ESR Mean } \pm \text { SD } \\
(\mathbf{m m} / \mathbf{1} \text { st } \mathbf{h r}) \\
(\mathbf{n = 1 6 1 )}\end{array}$ & F-value & P-value \\
\hline Stage $1(\mathrm{n}=161)$ & $23.78 \pm 18.011$ & 2.705 & 0.011 \\
\hline Stage 2 $(\mathrm{n}=75)$ & $27.77 \pm 19.072$ & & \\
\cline { 1 - 2 } Stage 3a $(\mathrm{n}=12)$ & $36.17 \pm 27.092$ & \\
\cline { 1 - 2 } Stage 3b (n=1) & 5.00 & \\
\cline { 1 - 2 } Stage 4 (n=1) & 60.00 & \\
\hline \multicolumn{2}{|c|}{ Table 9. Mean ESR distribution at various Stages } \\
\hline
\end{tabular}

Table 9 shows mean ESR value in different stages.

Stage 3a having the highest mean ESR value $(36.17 \pm 27.092)$ and stage $3 \mathrm{~b}$ have the lowest $\left(5.00 \mathrm{~mm} / 1^{\text {st }}\right.$ hour). P-value was found to be statistically significant ( $p$ value $=0.011$ ).

\begin{tabular}{|c|c|c|c|}
\hline & PCV Mean \pm SD & F-value & P-value \\
\hline Stage 1 $(n=161)$ & $41.72 \pm 6.54$ & 2.785 & 0.027 \\
\hline Stage 2 (n=75) & $39.47 \pm 5.24$ & \\
\cline { 1 - 2 } Stage 3a $(n=12)$ & $38.50 \pm 3.93$ & \\
\cline { 1 - 2 } Stage 3b $(n=1)$ & 50.00 & \\
\cline { 1 - 2 } Stage 4 (n=1) & 40.50 & \\
\cline { 1 - 1 } Total (n=250) & $\mathbf{4 0 . 9 2 \pm 6 . 1 6 8}$ & \\
\cline { 1 - 1 } Table 10. Correlation of Mean Packed Cell Volume and \\
Staging of Chronic Kidney Disease \\
\hline
\end{tabular}

Table 10 shows the mean Packed Cell Volume (PCV) was found to be $40.92 \pm 6.168$. The mean packed cell volume distribution of patients in different stages of CKD shows mean PCV of stage $3 \mathrm{~b}$ was having highest value. Packed cell volume value was found to be statistically significant $(\mathrm{p}<0.05)$.

\begin{tabular}{|c|c|c|}
\hline Platelet Level (lacs/cumm) & Frequency & Percentage \\
\hline $1.5-4.1$ & 248 & $99.2 \%$ \\
\hline$>4.1$ & 2 & $0.8 \%$ \\
\hline \multicolumn{2}{|c|}{ Table 11. Distribution of Platelet Level } \\
\hline \multicolumn{2}{|c|}{}
\end{tabular}

Table 11 shows maximum number of patients (99.2\%) have platelet level within normal limit, except 2 (two) patients have thrombocytosis. The mean platelet level was found to be $(2.35 \pm 0.606)$ lakhs/cumm.

\begin{tabular}{|c|c|c|c|}
\hline & $\begin{array}{c}\text { MCV Mean } \pm \\
\text { SD (fL) }\end{array}$ & $\begin{array}{c}\text { F- } \\
\text { value }\end{array}$ & $\begin{array}{c}\text { P- } \\
\text { value }\end{array}$ \\
\hline Stage 1 (n=161) & $84.80 \pm 6.171$ & 0.356 & 0.840 \\
\hline Stage 2 (n=75) & $84.34 \pm 6.565$ & \\
& Stage 3a (n=12) & $84.28 \pm 8.127$ & \\
\hline Stage 3b (n=1) & 78.00 & \\
\hline Stage 4 (n=1) & 86.00 & \\
\cline { 1 - 2 } Total & $\mathbf{8 4 . 6 1 \pm 6 . 3 5 8}$ & \\
\cline { 1 - 2 } Table 12. Correlation of Mean MCV (Mean Corpuscular \\
Volume) with Stages of Chronic Kidney Disease \\
\hline
\end{tabular}

Table 12 shows the distribution of mean MCV at different stages. The mean MCV (Mean Corpuscular Volume) was found to be $(84.61 \pm 6.358) \mathrm{fL}$. Mean MCV at stage $3 \mathrm{~b}$ is lowest with a value of $78 \mathrm{fL}$ and highest at stage 4 with a value of 86 fL. Correlation of MCV with stages of chronic kidney disease was not found to be statistically significant ( $p$-value=0.840).

The mean MCH distribution in various stages of CKD (Chronic Kidney Disease) are given below.

\begin{tabular}{|c|c|c|c|}
\hline & Mean MCH \pm SD (pg) & F-value & P-value \\
\hline Stage $1(\mathrm{n}=161)$ & $28.25 \pm 2.620$ & 0.473 & 0.756 \\
\hline Stage $2(n=75)$ & $28.13 \pm 2.764$ & & \\
\hline Stage $3 a(n=12)$ & $28.27 \pm 2.724$ & & \\
\hline Stage $3 b(n=1)$ & 26.00 & & \\
\hline Stage $4(n=1)$ & 31.00 & & \\
\hline Total & $28.22 \pm 2.658$ & & \\
\hline
\end{tabular}

Table 13 shows the mean $\mathrm{MCH}$ was found to be $(28.22 \pm 2.658) \mathrm{pg}$. The mean MCH value was similar in stages 1,2 , 3a. Value was low in stage $3 \mathrm{~b}$ (26 pg) and high at stage 4 (31 pg). It was not found to be statistically significant (pvalue $>0.05$ ).

\begin{tabular}{|c|c|c|c|}
\hline & Mean MCH \pm SD & F-value & P-value \\
\hline Stage 1 $(\mathrm{n}=161)$ & $32.80 \pm 2.832$ & 0.535 & 0.710 \\
\hline Stage 2 $(\mathrm{n}=75)$ & $33.16 \pm 1.378$ & \\
\\
Stage 3a $(\mathrm{n}=12)$ & $33.34 \pm 1.135$ & \\
\hline Stage 3b $(\mathrm{n}=1)$ & 31.00 & \\
\cline { 1 - 2 } Stage 4 $(\mathrm{n}=1)$ & 32.40 & \\
\cline { 1 - 2 } Total & $\mathbf{3 2 . 9 2 \pm 2 . 4 1 3}$ \\
\cline { 1 - 2 } Table 14. Correlation of Mean MCHC with \\
various Stages of CKD \\
\hline
\end{tabular}

Table 14 shows distribution of mean MCHC in different stages. The mean MCHC was found to be $(32.92 \pm 2.413) \mathrm{g} / \mathrm{dL}$ with the lowest MCHC in stage 3b. MCHC was not found to be statistically significant ( $p$ - value $>0.05$ ). 


\begin{tabular}{|c|c|c|}
\hline $\begin{array}{l}\text { Absolute Neutrophil } \\
\text { Count }\end{array}$ & $\begin{array}{c}\text { Frequency } \\
(n=250)\end{array}$ & Percentage \\
\hline$<2000 / \mathrm{dL}$ & 9 & $3.6 \%$ \\
\hline $2000-7000 / \mathrm{dL}$ & 214 & $85.6 \%$ \\
\hline$>7000 \mathrm{dL}$ & 27 & $10.8 \%$ \\
\hline Total & 250 & $100 \%$ \\
\hline
\end{tabular}

Table 15 shows the frequency distribution of Absolute Neutrophil Count. Maximum number of patients were found to have Absolute Neutrophil Count within normal range ( $\mathrm{n}=214,85.6 \%)$, while $27(10.8 \%)$ patients were having higher absolute count and only 9 (3.6\%) patients were having Neutropenia.

\begin{tabular}{|c|c|c|}
\hline $\begin{array}{c}\text { Absolute Lymphocyte } \\
\text { Count(/dL) }\end{array}$ & $\begin{array}{c}\text { Frequency } \\
\text { (n=250) }\end{array}$ & Percentage \\
\hline$<1000 / \mathrm{dL}$ & 4 & $1.6 \%$ \\
\hline $1000-3000 / \mathrm{dL}$ & 213 & $85.2 \%$ \\
\hline$>3000 / \mathrm{dL}$ & 33 & $13.2 \%$ \\
\hline Total & $\mathbf{2 5 0}$ & $\mathbf{1 0 0} \%$ \\
\hline \multicolumn{2}{|c|}{ Table 16. Distribution of Absolute Lymphocyte Count } \\
\hline
\end{tabular}

Table 16 shows that $85.2 \%(n=213)$ of the patients were having absolute lymphocyte count within normal range, while $13.2 \%(n=33)$ of the patients have Lymphocytosis and only $1.6 \%(n=4)$ had Lymphopenia.

\begin{tabular}{|c|c|c|}
\hline $\begin{array}{c}\text { Absolute Monocyte } \\
\text { Count (dL) }\end{array}$ & $\begin{array}{c}\text { Frequency } \\
(\mathbf{n = 2 5 0})\end{array}$ & Percentage \\
\hline$<200 / \mathrm{dL}$ & 20 & $8 \%$ \\
\hline $200-1000 / \mathrm{dL}$ & 225 & $90 \%$ \\
\hline$>1000 / \mathrm{dL}$ & 5 & $2 \%$ \\
\hline Total & $\mathbf{2 5 0}$ & $\mathbf{1 0 0 \%}$ \\
\hline \multicolumn{2}{|c|}{ Table 17. Distribution of Absolute Monocyte Count } \\
\hline
\end{tabular}

As evident from Table 17 , only $2 \%(n=5)$ of the patients had Monocytosis and $8 \%(n=20)$ of the patients had Monocytopaenia. While maximum number $(90 \%, n=225)$ of patients have normal Absolute Monocyte Count.

\begin{tabular}{|c|c|c|}
\hline $\begin{array}{c}\text { Absolute Eosinophil } \\
\text { Count }\end{array}$ & $\begin{array}{c}\text { Frequency } \\
(n=250)\end{array}$ & Percentage \\
\hline$<20 / \mathrm{dL}$ & 7 & $2.8 \%$ \\
\hline $20-500 / \mathrm{dL}$ & 228 & $91.2 \%$ \\
\hline$>500 / \mathrm{dL}$ & 15 & $6 \%$ \\
\hline Total & 250 & $100 \%$ \\
\hline
\end{tabular}

In Table 18, Eosinophilia was seen in $6 \%(n=15)$ of the patients and 2.8\% $(n=7)$ of the patients had Eosinopenia and majority $91.2 \%(n=228)$ of the patients had normal Absolute Eosinophil Count.

Only 1 (one) patient had $0.005 \%$ Basophil.

\begin{tabular}{|c|c|c|c|c|c|}
\hline & 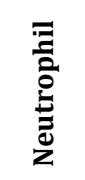 & 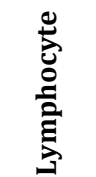 & 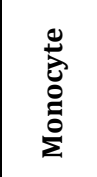 & 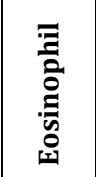 & $\begin{array}{l}\bar{z} \\
\overline{0} \\
\overline{0} \\
\overline{0} \\
0\end{array}$ \\
\hline Pearson Correlation & 0.121 & -0.051 & -0.118 & -0.133 & -0.042 \\
\hline P-value & 0.57 & 0.423 & 0.063 & 0.035 & 0.510 \\
\hline Number & 250 & 250 & 250 & 250 & 250 \\
\hline
\end{tabular}

Table 19 shows the correlation of different components of DLC (Differential Leucocyte Count). It was observed that Absolute Eosinophil Count was found to be statistically significant ( $p$-value $<0.05$ ).

\begin{tabular}{|c|c|c|c|}
\hline & Mean RDW \pm SD & F-value & P-value \\
\hline Stage $1(\mathrm{n}=161)$ & $13.52 \pm 1.137$ & 0.734 & 0.569 \\
\hline Stage $2(n=75)$ & $13.77 \pm 1.275$ & & \\
\hline Stage $3 a(n=12)$ & $13.69 \pm 0.738$ & & \\
\hline Stage $3 b(n=1)$ & 14.20 & & \\
\hline Stage $4(n=1)$ & 14.20 & & \\
\hline Total & $13.61 \pm 1.164$ & & \\
\hline
\end{tabular}

Table 20 RDW distribution in various stages of CKD. The mean RDW (Red Cell Distribution) was found to be $(13.61 \pm 1.164) \%$. While stage $3 \mathrm{~b}$ and stage 4 have higher RDW (14.20\%). All the other stages have similar range. RDW was not found to be significant ( $p$-value=0.569).

\begin{tabular}{|c|c|c|c|}
\hline & $\begin{array}{c}\text { Mean } \\
\text { Serum Creatinine } \pm S D \\
(\mathrm{mg} / \mathrm{dL})\end{array}$ & $\begin{array}{c}\text { F- } \\
\text { value }\end{array}$ & $\begin{array}{c}P \text { - } \\
\text { value }\end{array}$ \\
\hline Stage $1(\mathrm{n}=161)$ & $0.69 \pm 0.155$ & 29.873 & 0.000 \\
\hline Stage $2(n=75)$ & $0.83 \pm 0.174$ & & \\
\hline Stage $3 a(n=12)$ & $0.97 \pm 0.228$ & & \\
\hline Stage $3 b(n=1)$ & 1.80 & & \\
\hline Stage $4(n=1)$ & 1.50 & & \\
\hline Total $(n=250)$ & $0.75 \pm 0.199$ & & \\
\hline Table & $\begin{array}{c}\text { Correlation of Serum C } \\
\text { with Stages of CKD }\end{array}$ & tinine & \\
\hline
\end{tabular}

Table 21 shows mean creatinine level was found to be $0.75 \pm 0.199 \mathrm{mg} / \mathrm{dL}$. The mean serum creatinine value gradually increases as the stage increases. Serum creatinine value was found to be statistically highly significant ( $p$ value $=0.000$ ).

\begin{tabular}{|c|c|c|}
\hline Microalbuminuria & No. of Cases (Total n=250) & Percentage \\
\hline Present & 9 & $3.6 \%$ \\
\hline Absent & 241 & $96.4 \%$ \\
\hline
\end{tabular}

Table 22. Frequency distribution of Microalbuminuria

Table 22 shows the frequency distribution of microalbuminuria. Majority of the patients $(n=241,96.4 \%)$ have no microalbuminuria, while only 9 cases have microalbuminuria.

\begin{tabular}{|c|c|c|}
\hline & Frequency & $\mathbf{\%}$ \\
\hline Microcytic hypochromic anaemia & 29 & $11.6 \%$ \\
\hline Microcytic normochromic blood picture & 2 & $0.8 \%$ \\
\hline Normocytic normochromic anaemia & 21 & $8.4 \%$ \\
\hline $\begin{array}{c}\text { Normocytic normochromic blood } \\
\text { picture }\end{array}$ & 198 & $79.6 \%$ \\
\hline Total & $\mathbf{2 5 0}$ & $\mathbf{1 0 0 . 0 \%}$ \\
\hline Table 23. Frequency distribution of Blood Picture \\
\hline
\end{tabular}

Table 23 shows the frequency distribution from the peripheral blood picture. As is evident from the table, the most frequent peripheral smear picture seen was normocytic normochromic blood picture $(n=198)$. Only two types of anaemia were seen. Normocytic normochromic anaemia $(n=21)$ and microcytic hypochromic anaemia $(n=29)$ were seen. Only two patients $(n=2)$ had microcytic normochromic red blood cells. 


\section{DISCUSSION}

Chronic kidney disease is a progressive renal disease characterised by various manifestations and haematological abnormalities. The present study shows larger number of patients in age group of 35-55 years of age with mean age being 46.16 years, which is similar to studies by Anees et al[6] showing a mean age of $42.59 \pm 13.72$ years and Sawjib Borphukan et al[7] showing a mean age of $47.70 \pm 17.58$ years.

The study shows a higher number of patients are females $(52.8 \%)$ as opposed to males (47.2\%). This is in contrast to the other studies where male preponderance is seen as in studies by Anees et al[6] (male 61.3\%), Sawjib Borphukan et al[7] (male 62\%) and Kallol Bhattacharjee et al[8] (Male 65\%).

Majority of the patients $(n=161,64.4 \%)$ in the study were in stage 1 CKD followed by stage $2(n=75,30 \%)$ and stage $3 a$ $(n=12,4.8 \%)$ and one patient in each of stage $3 \mathrm{~b}$ and stage 4 CKD. None of the patients were found to be of stage 5. Study by Osama El-Minshawy et al[9] show maximum number of patients in stage $3(45 \%)$ and stage $2(36 \%)$ and study by Sheth Nidhi et al[10] shows $85 \%$ of patients in stage 5 followed by stage $4(8 \%)$ and stage $3(7 \%)$.

Haemoglobin ranged from $6.9 \mathrm{gm} \%$ to $17.9 \mathrm{gm} \%$ with a mean haemoglobin of $13.28 \mathrm{gm} \%$. Anaemia was present in $20 \%(n=50)$ of the cases. $58 \%$ of the anaemias were microcytic hypochromic anaemia, while $42 \%$ were normocytic normochromic anaemias. Haemoglobin level was found to be highly significant with stages of chronic kidney disease ( $p$-value=0.005). The finding is similar with the studies done by Suresh M et al[11] and Kallol Bhattacharya et al.[8]

The mean total leucocyte count in the present study was found to be $7909 \pm 2396.594(/ \mathrm{cmm})$, which was similar to the findings in the study done by Fu-Mei Chung et al.[12]

Absolute eosinophil count in correlation with different stages of chronic kidney disease was found to be statistically significant with a p-value of 0.035 , which is comparable to the studies done by Md. Jahangir Alam et al[13] with a p-value $<0.001$ and study done by Fu-Mei Chung et al[12] with a pvalue of 0.002 .

The mean platelet level was found to be $(2.35 \pm 0.606)$ lakhs $/ \mathrm{cmm} .99 .6 \%$ of the patients had platelet count within normal limit. Only one patient had thrombocytosis. The mean platelet count was similar to the finding in the study by Dhirendra Kumar Shukla et al[14] having a mean platelet count of (216.16 \pm 82.59$)$ lakhs $/ \mathrm{cmm}$.

The mean ESR value was found to be $(25.54 \pm 19.089)$ $\mathrm{mm} / 1^{\text {st }}$ hour. Higher number of patients $(58.4 \%)$ have higher level of ESR. ESR value was found to be statistically significant ( $p$ value $=0.011$ ). The mean ESR value is higher in a study done by Md. Jahangir Alam[13] et al with a value of $34.74 \pm 27.67 \mathrm{~mm} / 1^{\text {st }}$ hour and p-value of 0.016 .

Mean Packed Cell Volume (PCV) was found to be (40.92 \pm 6.168$) \%$, which was higher than a study by Suresh M et al[11] with a value of $(27.13 \pm 4.41) \%$. The mean PCV decreases from stage 1 to stage 2 and stage 3 a.

Mean MCV (Mean Corpuscular Volume) was found to be $(84.61 \pm 6.358) \mathrm{fL}$, which is comparable to the study done by Chralampos Loutradis et al[15] having mean MCV value of 87.62 $\pm 6.99 \mathrm{fL}$. The Mean Corpuscular Haemoglobin (MCH) was found to be $(28.22 \pm 2.658) \mathrm{pg}$, which is slightly lower than in a study done by Chralampos Loutradis et al[15] having a value of $29.91 \pm 5.08 \mathrm{pg}$.

Mean Corpuscular Haemoglobin Concentration (MCHC) was observed to be $(32.92 \pm 2.413) \mathrm{g} / \mathrm{dL}$, which is similar to the study by Chralampos Loutradis et al[15] $(32.38 \pm 1.76)$ g/dL.

The mean RDW (Red Cell Distribution) was found to be $(13.61 \pm 1.164) \%$. Mean RDW gradually increases from stage 1 to stage 4 . P-value was not statistically significant.

Mean eGFR value was found to be $104.19 \pm 31.369$ $\mathrm{mL} / \mathrm{min} / 1.73 \mathrm{~m}^{2}$. The eGFR value gradually decreases from stage $1 \quad\left(121.33 \pm 24.883 \quad \mathrm{~mL} / \mathrm{min} / 1.73 \quad \mathrm{~m}^{2}\right)>$ stage 2 $\left(76.94 \pm 8.499 \mathrm{~mL} / \mathrm{min} / 1.73 \mathrm{~m}^{2}\right)>$ stage 3 a $\quad(56.49 \pm 2.132$ $\left.\mathrm{mL} / \mathrm{min} / 1.73 \mathrm{~m}^{2}\right)>$ stage $3 \mathrm{~b}\left(38.80 \mathrm{~mL} / \mathrm{min} / 1.73 \mathrm{~m}^{2}\right)>$ stage 4 (26.66 mL/min/1.73 $\mathrm{m}^{2}$ ).

Mean creatinine level was found to be $0.75 \pm 0.199 \mathrm{mg} / \mathrm{dL}$. There is gradual rise in creatinine from stage 1 to stage 4 . The serum creatinine level is increased in diabetic patients with renal dysfunction, which is found to be statistically highly significant ( $p$-value $=0.000$ ).

\section{CONCLUSION}

- Haematologic abnormalities are common in Diabetics, especially when associated with renal dysfunction.

- Anaemia is the most common haematologic abnormality observed.

- Normocytic Normochromic Anaemia and Microcytic Hypochromic Anaemia are the two types of anaemia observed.

- Maximum number of cases were in stage 1 of CKD with eGFR $>90 \mathrm{~mL} / \mathrm{min} / 1.73 \mathrm{~m}^{2}$. This may be because, in this study there were only newly diagnosed type 2 Diabetes Mellitus cases.

- $\quad$ ESR was higher with a mean value of $25.64 \pm 19.089$ $\mathrm{mm} / 1^{\text {st }}$ hour and shows positive correlation with stages of CKD.

- The Haematocrit was found to be statistically significant upon correlation with stages of CKD.

\section{REFERENCES}

[1] Powers AC. Diabetes Mellitus. In: Longo DL, Kasper DL, Jameson JL, et al. eds. Harrison's Principles of Internal Medicine. 19th edn. United States of America: The McGraw-Hill Companies Inc., 2012.

[2] Ebrahim S, Kinra S, Bowen L, et al. The effect of ruralto-urban migration on obesity and diabetes in India: a cross-sectional study. PLoS Med 2010;7(4):e1000268.

[3] Al-Khuory S, Afzali B, Shah N, et al. Diabetes, kidney disease and anaemia: time to tackle a troublesome triad? Int J Clin Pract 2007;61(2):281-9.

[4] Desforges JF. Anemia in uremia. Arch Intern Med 1970;126(5):808-11.

[5] Astor BC, Muntner P, Levin A, et al. Association of kidney function with anemia: the Third National Health and Nutrition Examination Survey (19881994). Arch Intern Med 2002;162(12):1401-8.

[6] Anees M, Khan JA, Basit A, et al. Refusal of dialysis amongst patients of chronic kidney disease (CKD). Annals King Edward Med Uni 2014;20(3):228-32. 
[7] Borphukan S, Gogoi S. A study on the clinicoaetiological profile of patients with chronic kidney disease in North-East India: a hospital based study. J Evid Based Med Healthc 2016;3(56):2910-6.

[8] Bhattacharjee K, Das D, Rabha P, et al. A study on hematological profile in patients of chronic renal failure with special reference to serum iron profile. Journal of Evidence based Medicine and Healthcare 2015;2(46):8212-9.

[9] El-Minshawy 0, El-Bassuoni E. Anemia and kidney dysfunction in type 2 diabetic patients. Int J Nephrol Urol 2010;2(4):543-52.

[10] Nidhi SV, Shaila SN. Clinico-hematological study of chronic kidney disease. International Journal of Science and Research 2015;4(10):1825-8.

[11] Suresh M, Reddy MN, Singh SBM, et al. Hematological changes in chronic renal failure. International Journal of Scientific and Research Publications 2012;2(9):1-4.
[12] Chung FM, Tsai JC, Chang DM, et al. Peripheral total and differential leucocyte count in diabetic nephropathy: the relationship of plasma leptin to leucocytosis. Diabetes Care 2005;28(7):1710-7.

[13] Alam MJ, Mallik SC, Mukti MNTM, et al. A comparative analysis of biochemical and hematological parameters in diabetic and non-diabetic adults. Advanced Medical Sciences: An International Journal (AMS) 2015;2(1)19.

[14] Shukla DK, Chandra KP, Pawah AK. Study of hematological indices in patients with diabetes mellitus and hypertensive diabetes mellitus. International Journal of Medicine Research 2016;1(4):28-31.

[15] Loutradis C, Skodra A, Georgianos P, et al. Diabetes mellitus increases the prevalence of anemia in patients with chronic kidney disease: a nested case-control study. World J Nephrol 2016;5(4):358-66. 